\title{
Perceptions, Attitudes, and Teaching about Death and Dying in the Medical School of the Federal University of Acre, Brazil
}

\section{Percepção, Atitudes e Ensino sobre a Morte e Terminalidade da Vida no Curso de Medicina da Universidade Federal do Acre}

\author{
Daniel Teixeira Marques \\ Marcelo Xavier de Oliveira \\ Maria Liliane Gomes dos Santos ${ }^{I}$ \\ Rodrigo Pinheiro Silveiral \\ Romeu Paulo Martins Silval
}

\section{KEY-WORDS}

- Attitude to Death.

- Death.

- Medical Education.

- Medical Students.

- Palliative Care.

- Terminal Care.

- Terminally ill.

\begin{abstract}
Death is one of the major taboos of contemporary Western society and is a forbidden and avoided subject. If in the past it was a public and domestic event, nowadays it is hidden in hospitals crowded with professionals who are unprepared to deal with issues related to the end of life. This unpreparedness is a reflex of excessively technical and non-humanistic training which favors healing over caring. Therefore, it seems medical students are taught to work against death and not with it. In this context, we sought to trace the profile of attitudes towards death of the students graduating from the Medicine course of a public university in Brazil and evaluate how this course has prepared them to deal with issues of death and dying in their perception. We employed quantitative and qualitative methodologies by applying two data collection instruments: a questionnaire to collect sociodemographic and academic data as well as data on the teaching about death, and another to define the profile of attitudes towards death (DAP-R). We analyzed the studied variables descriptively using frequencies and means, and intercorrelated them to infer the hypotheses. We also considered student statements for analysis and discussion of results based on comments on the responses to one of the questionnaires. As results, we observed that the students' attitude towards death was characterized by a view of death as a natural event of life (neutral acceptance), while their imagination about death was permeated with conflicting feelings; that most students had experienced the death of a patient during the course (75.8\%) although most of those received no guidance in these situations (80\%); that the humanistic courses concentrated the approaches on death; and that such approaches somewhat contributed to create reflection and develop abilities for managing death. We concluded that teaching about death and dying is still concentrated in few courses of the medical curriculum, mainly in the humanistic ones, and is excessively theoretical, whereas the real experiences with death during the Medicine course are treated with detachment and silence when they could be better utilized for teaching and learning about the end of life.
\end{abstract}




\section{PALAVRAS-CHAVE}

- Assistência Terminal.

- Atitude frente à Morte.

- Doente Terminal.

- Educação Médica.

- Estudantes de Medicina.

- Medicina Paliativa.

- Morte.

\section{RESUMO}

Entre os vários tabus da sociedade ocidental contemporânea, a morte figura como um dos principais. É assunto interdito e evitado. Se no passado ela era um evento público e doméstico, hoje se encontra oculta nos hospitais, que, por outro lado, estão abarrotados de profissionais despreparados para lidar com as questões relativas ao fim da vida, reflexo de uma formação excessivamente tecnicista e pouco humanística, que privilegia o curar em detrimento do cuidar. Dessa forma, parece que o estudante de Medicina é ensinado a trabalhar contra a morte e não com a morte. Nesse contexto, buscou-se traçar o perfil de atitudes dos estudantes concluintes do curso de Medicina da Ufac perante a morte $e$ avaliar como esse curso tem preparado os estudantes para lidar com assuntos referentes à morte $e$ ao morrer, considerando a percepção dos próprios discentes. Foram utilizadas metodologias quanti e qualitativas, com aplicação de dois instrumentos para a coleta de dados: um questionário para a coleta de dados sociodemográficos e acadêmicos e sobre o ensino da morte, e outro para a definição do perfil de atitudes perante a morte (Eapam-R). As variáveis de estudo foram analisadas de forma descritiva, com frequência e médias, e correlacionadas entre si para inferência das hipóteses. O discurso dos estudantes também foi considerado para análise e discussão dos resultados com base em comentários escritos sobre as respostas a um dos questionários. Verificou-se que a postura dos estudantes perante a morte foi caracterizada por uma visão da morte como algo natural (aceitação neutral), ao mesmo tempo em que o imaginário sobre a morte estava permeado de sentimentos conflitantes; que a maioria dos estudantes havia vivenciado situações de morte de um paciente ao longo do curso (75,8\%), porém poucos receberam orientação nessas situações (80\%); que a abordagem sobre a morte esteve concentrada em disciplinas de caráter humanístico, tendo contribuído pouco para gerar reflexão $e$ desenvolver habilidades para manejo das situações de morte. Conclui-se que o ensino sobre a morte e o morrer ainda está concentrado em poucas disciplinas do currículo médico, principalmente nas de caráter humanístico, e é excessivamente teórico, sendo que as experiências reais com a morte durante a graduação são tratadas com distanciamento e silêncio, quando poderiam ser mais bem aproveitadas no ensino-aprendizagem sobre o fim da vida.

Recebido em: 12/12/18

Aceito em: 4/2/19

\section{INTRODUCTION}

Death is a universal phenomenon inherent to the human condition and to that of other species which implies multiple meanings. For Rodrigues ${ }^{1}$, death is a concept seized from the environment, built from a lifetime of relationships, influenced by traditions, beliefs, rules, and by the sociocultural context and historical moment in which the individual lives. Not all peoples deal with death in the same way ${ }^{1}$.

In making a historical analysis of the relationship of the Western man with death, Philippe Ariès ${ }^{2}$ reported that, in the past, death was part of the everyday scene of life, it was natural and familiar. The dying person died at home surrounded by relatives and friends and cemeteries were a public space of socialization where parties, dances, and commercial activities took place without any concern for the dead buried there or the ossuaries accumulated all around.
However, over the centuries, the intimacy of the Western man with death gave way to an attitude of fear and detachment, transforming it into a social taboo. Nowadays, death is a forbidden subject - prohibited - and this is related to the fact that it exposes human frailty, raises the idea of self-finitude, and weakens the "defensive fantasies that people build as a wall around the idea of their own death", as Norbert Elias 2,3 stated.

In fearing death, it is natural for a person to want to get as far away from it as possible and this was how, throughout the twentieth century, death went from a domestic and familiar environment to the cold, isolated, and "hidden" environment of hospital beds. Hence, the sorrow, suffering, and personal and family dramas aroused by the end of life were incorporated into the routine of health professionals, who are not always well prepared to face such an emotional load since Health 
Science courses, especially medical schools, are still flawed in their discussing and teaching about death and dying ${ }^{2,3}$.

The curricula of medical courses often do not include courses on death and related matters such as communicating bad news, mourning, euthanasia, the non-scientific views of death, and patient spirituality. When they graduate, young physicians feel unprepared for the end-of-life issues with which they learn to deal with - properly or not - during their professional lives. The fact is that the current training of health professionals - especially physicians - is still primarily based on healing instead of caring, a vestige of the biomedical model. The student is taught that disease must be "combated" and the primary goal becomes healing, while death is viewed as the victory of the pathology over the health professional. Hence, in the current medical training scenario, the medical student learns to work against death and not with it ${ }^{4-6}$.

Bernard Lown (1997), quoted by Siqueira (p. 22) ${ }^{7}$, asserted that

Medical schools and hospital internships prepare them [future physicians] to become senior science officials and managers of complex biotechnologies. Very little is taught about the art of being a physician. Physicians learn very little about dealing with terminally ill patients [...]. The most fundamental reality is that there has been a biotechnological revolution that enables the endless prolongation of dying.

The terminality of life, as well as the suffering, fear, and anxieties aroused by it, are a constant reality in the routine of health workers, which justifies the need for guidance on this subject during medical school. Based on this premise, we developed this study with the primary objective of tracing the profile of attitudes towards death of senior medical students from the Federal University of Acre, Brazil (UFAC), and to describe the teaching about death and dying in this school from the students' point of view.

\section{METHODS}

We performed a transversal, exploratory, and descriptive scientific investigation using quantitative and qualitative methods to achieve the proposed objectives.

The target audience of this study were students enrolled in the eighth and eleventh terms of the UFAC Medicine course who, having already completed most of the course and had accumulated more practical experience and were more capable of evaluating the teaching about death and dying. The inclusion criteria for participation in the study were: to be enrolled on the UFAC Medicine course, to attend all the courses of the eighth or eleventh terms, and to be over eighteen years old. The exclusion criteria were: being under eighteen years old and not attending all the courses of the eighth or eleventh terms.

For data collection, we applied two instruments: the Death Attitude Profile - Revised (DAP-R) and the sociodemographic and assessment of teaching about death questionnaire. The DAP-R, created in 1991 in English, was validated for Portuguese in 2010 and, from the answers to 32 items graded in seven agreement levels by the Likert scale, allowing to define three types of attitudes towards death: fear, avoidance, and acceptance, with the latter further subdivided into three types: neutral acceptance, religious/approach acceptance, and escape acceptance. According to the authors, both fear and acceptance of death are related to the search for a meaning for life and are not exclusive as they may coexist in a person. Accepting death implies being prepared for the end of existence, which may be faced in three different ways: death as part of life itself (neutral acceptance); death as the beginning of another life (religious/approach acceptance); and death as the end of a life of pain and suffering (escape acceptance). Finally, there are people who "run away" from death, avoiding talking and thinking about it, thus characterizing death avoidance ${ }^{8,9}$.

A questionnaire was developed to collect sociodemographic information as well as data on the teaching about death and end-of-life care. This instrument was developed from the perspective of qualitative research aiming to contemplate not only numerical information but also statements given by students. We performed a preselection of aspects of teaching about death in the Medicine course that would be addressed in this study, namely: death in the students' imagination, quality of approach to the subject, extracurricular activities related to death and dying, experiencing the death of a patient during the course, guidance in death situations, and preparation to deal with death. Each of these aspects was the basis of an item of the questionnaire and, in the end, constituted the analysis categories for discussing the results. Also, at the end of each question, we provided a free space so the participants could make written comments and observations that complemented and/or justified their answer to each question. Thus, as a semi-structured interview, the dialog between the researcher and the participants was guided by the questions and materialized in the written statements of the students, which then subsidized a better understanding of the quantitative data and provided a more in-depth analysis on the teaching of and experiencing death in the Medicine course. To correct flaws and make possible improvements to this instrument, we submitted it to a pilot test with ten voluntary stu- 
dents enrolled on various terms of the course before applying it to the target audience ${ }^{10,11}$.

We applied the questionnaires in March 2017, shortly after a test for the eighth term participants and through an active search of the eleventh term participants at their internship locations. Before presenting the questionnaires, we briefly presented the research project, clarified doubts, and delivered the Free and Informed Consent Forms.

We performed statistical analysis of the quantitative data using the SPSS 20.0 program. We calculated frequencies, means, and standard deviations for the descriptive analysis of the data. Analysis of variance for repeated measures (Anova-RM) and post-hoc de Bonferroni tests were used to check for any statistical difference between the profiles of attitudes toward death. We used the Pearson correlation and the t-test on independent samples for correlation and variable comparison, respectively.

This study was based on bioethical principles and norms established by Resolution 466/2012 of the Brazilian National Health Council and was approved by the Research Ethics Committee of the Hospital das Clínicas of the state of Acre, Brazil, report number 1.899 .727 and CAAE number 63351616.9.0000.5009.

\section{RESULTS}

The participation rate was $92.9 \%$, with five students choosing not to participate in the study. The mean age of the group was 26.76 years old (Min: 22; Max: 40; SD: 3.83). Seven participants did not inform their age. In general, the study participants were predominantly men, single, professing some religious faith, and on their first undergraduate course. Moreover, most students $(75.8 \%)$ reported experiencing the death of at least one patient during the course, even though $80 \%$ of them have not received any orientation for such a situation and 56.1\% declared having being poorly prepared to deal with terminal patients.

Regarding the quality of the approach to the themes, we proposed two concepts to the participants: deepening and sufficiency. Courses were considered "deepened" if they led to reflection in addressing the subject, and "sufficient" if they allowed the development of skills to deal with situations of death and end-of-life care. Hence, we offered four response options: "deepened and insufficient", "deepened and sufficient", "superficial and sufficient", and "superficial and insufficient". Table 1 shows the complete profile of the studied group and some aspects about students' perception of teaching about death and dying.

\begin{tabular}{|c|c|c|}
\hline $\begin{array}{r}\text { Sample character } \\
\text { of death ar }\end{array}$ & $\begin{array}{l}\text { TABLE } 1 \\
\text { ation and students' per } \\
\text { dying teaching }(n=66\end{array}$ & ption \\
\hline Variables & & n (\%) \\
\hline Torm in the cource & Eighth & $35(53 \%)$ \\
\hline ferm in the course & Eleventh & $31(47 \%)$ \\
\hline Gender & Men & $38(58.5 \%)$ \\
\hline Genaer & Women & $27(41.5 \%)$ \\
\hline & Single & $61(92.4 \%)$ \\
\hline Marital status & Married & $4(6.1 \%)$ \\
\hline & Stable union & $1(1.5 \%)$ \\
\hline & Some religious belief & $49(74.2 \%)$ \\
\hline Relig1on & No religion / Atheist & $17(25.7 \%)$ \\
\hline Provious aradultion & No & $54(81.8 \%)$ \\
\hline Previous graduation & Yes & $12(18.2 \%)$ \\
\hline Experience of a patient's & $\begin{array}{l}\text { Death of at least one } \\
\text { patient }\end{array}$ & $50(75.8 \%)$ \\
\hline & No death of a patient & $16(24.2 \%)$ \\
\hline & No guidance & $40(80 \%)$ \\
\hline & $\begin{array}{l}\text { Only on biological and } \\
\text { legal aspects }\end{array}$ & $4(8 \%)$ \\
\hline $\begin{array}{l}\text { Preceptor guidance in } \\
\text { patient death situations }\end{array}$ & $\begin{array}{l}\text { On biological and/ } \\
\text { or legal aspects and } \\
\text { on ethical and moral } \\
\text { aspects }\end{array}$ & $4(8 \%)$ \\
\hline & $\begin{array}{l}\text { Only on ethical and } \\
\text { moral aspects and on the } \\
\text { professional's posture }\end{array}$ & $2(4 \%)$ \\
\hline & $\begin{array}{l}\text { Superficial and } \\
\text { Insufficient }\end{array}$ & $32(48.5 \%)$ \\
\hline Quality of the approach & $\begin{array}{l}\text { Superficial and } \\
\text { Sufficient }\end{array}$ & $14(21.2 \%)$ \\
\hline & $\begin{array}{l}\text { Deepened and } \\
\text { Insufficient }\end{array}$ & $15(22.7 \%)$ \\
\hline & Deepened and Sufficient & $5(7.6 \%)$ \\
\hline & Unprepared & $12(18.2 \%)$ \\
\hline Prepare to deal with & Poorly prepared & $37(56.1 \%)$ \\
\hline terminal patients & Prepared & $17(25.8 \%)$ \\
\hline & Very prepared & $0(0 \%)$ \\
\hline
\end{tabular}

Initially, we sought to clarify how death is represented in the imagination of medical students. For this, we asked the participants to write the first word or expression that came to mind when they thought about death. Using Word Office $2013 \AA$, we developed a word cloud with the answers (Figure 1 ), in which the most prominent words are those that were more frequently cited.

Regarding the profiles of attitudes towards death, neutral acceptance had the highest mean followed by the religious/ approach acceptance, fear, avoidance, and escape acceptance with statistical difference $(\mathrm{p}<0.001)$ between all means except between fear and avoidance, fear and escape acceptance and avoidance and escape acceptance, as shown in Table 2. 
Figura 1

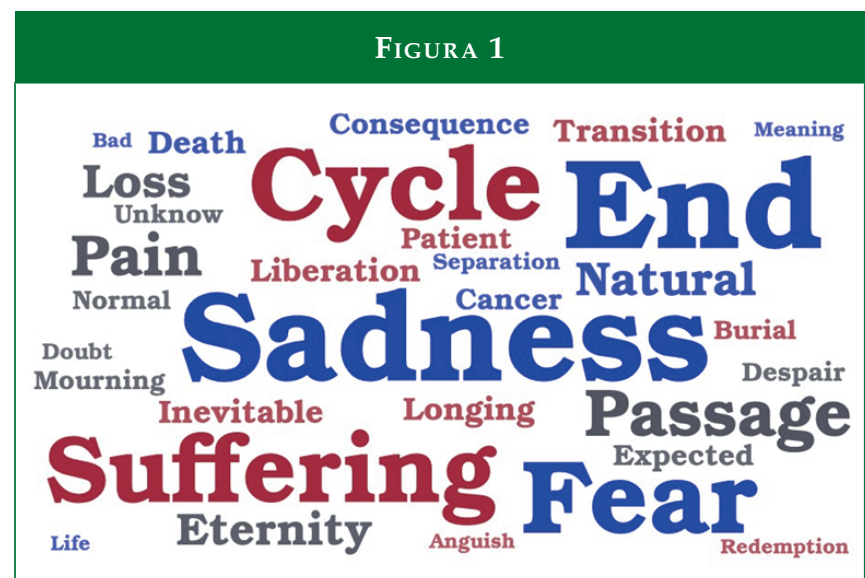

\begin{tabular}{|c|c|c|c|c|c|c|}
\hline & ttitu & $\begin{array}{r}\mathrm{T} \\
\text { prof }\end{array}$ & $\begin{array}{l}\text { E } 2 \\
\text { tow }\end{array}$ & Is de & & \\
\hline & & F & A & NA & RA & EA \\
\hline Mean & & 3.74 & 3.59 & 5.43 & 4.34 & 3.43 \\
\hline $\begin{array}{l}\text { Standard } \\
\text { Deviation }\end{array}$ & & 1.21 & 1.20 & 0.72 & 1.47 & 1.46 \\
\hline & F & & \# & * & * & $\#$ \\
\hline Statistical & A & \# & & * & * & \# \\
\hline $\begin{array}{l}\text { difference } \\
\text { between }\end{array}$ & NA & * & * & & * & $*$ \\
\hline means & RA & * & * & * & & * \\
\hline & EA & \# & \# & * & * & \\
\hline
\end{tabular}

F-Fear; A - Avoidance; NA - Neutral acceptance; RA - Religious/approach acceptance; EA - Escape acceptance; * $p<0.001$ (ANOVA-RM); \# - no statistical difference (post-hoc de Bonferroni)

We sought to establish how the different attitude profiles correlated with each other to understand the possible influences of one over another. We point out the negative relationship found between neutral acceptance and fear of death, as well as the positive relationship between religious/approach acceptance and the profiles of avoidance and escape acceptance (Table 3).

\begin{tabular}{lccccc}
\multicolumn{7}{c}{ TABLE 3 } \\
\multicolumn{7}{c}{ Correlations among attitude profiles } \\
\hline & F & A & NA & RA & EA \\
F & 1 & $0.457^{*}$ & $-0.395^{*}$ & 0.105 & 0.090 \\
\hline A & $0.457^{*}$ & 1 & -0.144 & $0.253^{*}$ & 0.212 \\
NA & $-0.395^{*}$ & -0.144 & 1 & -0.128 & 0.119 \\
\hline RA & 0.105 & $0.253^{*}$ & -0.128 & 1 & $0.481^{*}$ \\
EA & 0.090 & 0.212 & 0.119 & $0.481^{*}$ & 1 \\
\hline
\end{tabular}

F-Fear; A-Avoidance; NA - Neutral acceptance; RA-Religious/approach acceptance; EA - Escape acceptance; ${ }^{*} p<0.05$ (Pearson correlation)

Comparing the means of the attitude profiles towards death according to sociodemographic and academic variables, we observed that having a religion was associated with higher means for fear, religious/approach acceptance, and escape acceptance. On the other hand, having experienced the death of a patient during the course was related to lower means for religious/approach acceptance and escape acceptance. In turn, participating in extracurricular activities related to death and dying correlated with a lower tendency to avoid death (Table 4).

\section{TABLE 4}

Comparison between means of the attitude profiles towards death according to sociodemographic and academic variables

\begin{tabular}{|c|c|c|c|c|c|c|}
\hline & & F & A & NA & RA & EA \\
\hline \multirow{2}{*}{ Has a religion } & Yes $(n=49)$ & $3.92^{*}$ & 3.69 & $5.31^{*}$ & $4.87^{*}$ & $3.78^{*}$ \\
\hline & No $(n=17)$ & $3.21^{*}$ & 3.36 & $5.77^{*}$ & $2.82^{*}$ & $2.56^{*}$ \\
\hline \multirow{2}{*}{$\begin{array}{l}\text { Extracurricular } \\
\text { activity on death } \\
\text { and dying }\end{array}$} & 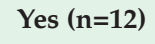 & 3.52 & $2.83^{*}$ & 5.50 & 4.15 & 3.51 \\
\hline & $100(11=04)$ & 3.79 & 3. & 2 & 4.38 & 3.41 \\
\hline \multirow{2}{*}{$\begin{array}{l}\text { Experienced the } \\
\text { death of a patient } \\
\text { during the course }\end{array}$} & Yes & 3.68 & 3.72 & 5.40 & $4.11^{*}$ & $3.20^{*}$ \\
\hline & No $(n=16)$ & 3.94 & 3.18 & 5.55 & $5.05^{*}$ & $4.12^{*}$ \\
\hline
\end{tabular}

F: fear; A: avoidance; NA: neutral acceptance; RA: religious/approach acceptance; $E A$ : escape acceptance; * $p<0.05$ (T-test on independent samples)

For a better view on the approach to the subject during medical training, we asked the participants to mention the courses that addressed some themes related to death mentioned on the questionnaire (Table 5). Three courses - Primary Care Axis, Bioethics, and Medical Psychology - were cited by more than half of the participants, concentrating the highest number of mentions.

\begin{tabular}{|c|c|}
\hline \multicolumn{2}{|l|}{$\begin{array}{r}\text { TABLE } 5 \\
\text { Courses that addressed themes }\end{array}$} \\
\hline & $\begin{array}{l}\text { Participants that } \\
\text { mentioned them } \\
n(\%)\end{array}$ \\
\hline Primary Attention Axis & $40(62.5 \%)$ \\
\hline Bioethics & $34(53.1 \%)$ \\
\hline Medical Psychology & $33(51.6 \%)$ \\
\hline Psychiatry & $21(14.1 \%)$ \\
\hline Epistemology & $7(4.7 \%)$ \\
\hline Philosophical Anthropology & $6(4 \%)$ \\
\hline Internal Medicine & $3(2 \%)$ \\
\hline Medical Semiology & $2(1.3 \%)$ \\
\hline Surgery & $1(0.7 \%)$ \\
\hline Infectious diseases & $1(0.7 \%)$ \\
\hline Addressed in another medical school & $1(0.7 \%)$ \\
\hline
\end{tabular}


We based the discussion on the analysis categories that were predefined to develop the sociodemographic and teaching about death questionnaire: death in the imagination of the students, quality of the approach to the subject, extracurricular activities related to death and dying, experiencing the death of a patient during the course, guidance in death situations, and preparation to deal with death. We evaluated these categories according to the multiple-choice answers to the questionnaire as well as from the student statements made as comments on the questions.

\section{DISCUSSION}

According to the specialized literature, death is a forbidden and avoided subject in Western society, as it generates anguish and suffering in a world where the rule is to search for happiness. When analyzing the imagination of medical students about death, one realizes that for them death continues to be a source of conflicting feelings - SUFFERING, FEAR, SADNESS. Death as a source of unpleasant feelings for medical students is also often described in other studies, which report students having feelings of failure, impotence, and malpractice in the face of death ${ }^{2,12}$.

If, on the one hand, death seems to provoke anguish and fear, on the other, in a seemingly contradictory way, we found that among the medical students the attitude profile that prevailed was characterized by a view of death as something natural (neutral acceptance). In a similar study, health students also showed a prevalence of the same profile. However, it is necessary to question the true character of this "neutrality" towards death among the students and if it is actually assimilated naturally ${ }^{8,13,14}$.

Firstly, we admit that students may profess ideologies and beliefs that transmit to them tranquility and serenity towards death, which would justify the preponderance of the neutral acceptance profile. However, the comments of two participants raised the hypothesis that the neutral attitude towards death may be more related to the routine of living with it in the hospital environment than to a sociocultural conception of death as a natural phenomenon:

It is incredible how the health professional over time begins to deal with death as if it were commonplace. When they see that the patient's condition is worsening and there is not much to do, they simply accept it and move on! [...]

The first death as the physician in charge of the patient is difficult, the tendency is to blame oneself for what happened. But with the hospital routine, deaths start to become more natural, especially if you do not get too involved with the patient.

Thus, the neutral acceptance profile possibly represents a kind of defense for the students that minimizes the fear of death, a posture possibly assimilated by the students from daily life with more experienced professionals. This is made explicit by the second comment, in which the participant admits difficulty upon first contact with death - something difficult for those who do not deal with it on a daily basis - but also reveals that the hospital routine, that is, living with death on a daily basis, helps make everything more "natural". Moreover, the negative relationship found between neutral acceptance and fear of death, in which the neutral attitude possibly reduces the fear of death, contributes to reinforcing the hypothesis of neutral acceptance as a defense mechanism in death situations.

Similarly, Duarte et al. ${ }^{12}$ reported in their research that for sixth-year medical students, death was part of the medical routine, although it still represented a "difficult experience" and a "taboo".

This defensive attitude through neutral acceptance must be viewed with care since, besides not guaranteeing security and tranquility in the face of death, it may merely represent an escape from something that remains frightening and complicated for the person, resulting in trivialization. This seems to be represented in the words of one of the participants quoted above, who stated that "not getting too involved" makes death more "natural". Eizirik et al. ${ }^{15}$ cautioned against this, stating that the banalization of dying in health care may lead to an "authoritarian and distant" attitude towards the patients and their families, compromising the quality of care offered.

On the other hand, one must consider that the conception of death and dying is not unique and is influenced by several factors. In this study, we were able to identify two groups of influences on the views and postures of the students towards death: sociocultural elements and academic experiences.

The sociocultural elements cover the set of beliefs, values, and experiences that the individual acquired before the undergraduate course, a result of their life of relations and that cannot be disregarded in the teaching-learning process. In this sense, we observed that religion is a sociocultural element that greatly influences the students' imagination about death. Words such as CYCLE, PASSAGE, and ETERNITY - linked to the religious concept of life after death - were strongly related to the idea of death by the participants. Also, the participants that professed a religion, compared to those who did not, presented a higher mean for religious/approach acceptance, 
attesting that faith may influence not only thought but also action in the face of death.

However, we observed a higher level of fear of death in the religious group compared to the non-religious participants, while the religious/approach acceptance profile was positively correlated with the death avoidance profile. If, on the one hand, personal experiences, beliefs, and values must not be ignored, such data point out that it is necessary to reflect on the type of influence that sociocultural elements exert on the view of death. Sometimes, it may be necessary to rethink them and give them new meanings during the undergraduate course.

The set of knowledge and experiences made possible by academic activities, regardless of whether they are in the course's formal curriculum, contribute in some way to reformulate the personal ideas and values when becoming a physician. Azeredo ${ }^{16}$ revealed that medical training caused a significant change in the view of death for $39.2 \%$ of medical students. In this study, experiencing the death of a patient exemplifies this, whereas having had such an academic experience was associated with a lower tendency to acceptance patterns possibly linked to experiences before the course such as religious acceptance.

The results also show that even the extracurricular activities, which are not formally in the course curriculum, may contribute to minimizing the tendency to avoid death, thus confirming the influence that academic experiences - whether formal or informal - may have on the attitude towards death. Mascia et al. ${ }^{17}$ suggested that experiences throughout the course may generate reflection and growth in situations that involve the end of life.

Experiencing the death of a patient during the medical course was relatively frequent among the participants. Moreover, such experiences may provoke the most varied sensations and emotions in students, not always positive, as revealed by the report of a participant:

You cannot live every day with a patient and not get shaken up and reflective when their condition gets worse, or they die. [...] The only thing I could think about was that I could have done more, I could have induced the preceptor to do more for the patient. Feeling incapable in your workplace is a terrible sensation, especially when working with lives, with something so definitive as death.

When studying the attitudes of medical students towards aspects of medical practice, Mascia et al. ${ }^{17}$ described there was a predominance of conflicting and negative feelings in situ- ations involving death, and alerted to the tendency to avoid the subject in the medical environment, an attitude named "conspiracy of silence". That is, when a patient dies, little or nothing is said about it, as we observed in this study in which the preceptor was silent in $80 \%$ of the cases where the death of a patient was experienced by the participants. One student wrote:

Of all the patient deaths I experienced as an intern, which were more than five, only one preceptor (resident) talked to me about it.

Hence, there seems to be an agreement among health professionals - including physicians - not to mention the feelings and emotions brought about by events in the professional practice such as the death of patients. Regrettably, this attitude of not discussing the situations of loss of a patient may be understood by the students as an indication that death is always something bad and difficult for the physician, and that silence and detachment are the most "adequate" attitudes in the face of death and dying.

In their study, Rhodes-Kropf et al. ${ }^{18}$ also reported that there was no discussion in $63 \%$ of the cases in which students experienced the death of a patient. The professor's silence in death situations is worrying not only due to the negative message it may send about death and dying but particularly because of the lack of support to the students' emotional experiences at such moments ${ }^{19}$.

Several studies have shown that feelings such as fear, incapacity, suffering, and questioning one's own conduct are common to medical students faced with the death of a patient. The same studies have asserted that students often feel helpless in such moments since rarely is there anyone to discuss the fact with them either because of insensitivity or unpreparedness of the health team itself in such situations ${ }^{16,18,20}$.

In this study, the participants also associated death with a series of conflicting feelings, with some students describing the experience of losing a patient as a "horrible feeling", "difficult", "shocking", and "a feeling of powerlessness".

The scarcity of guidance and discussion about death is troubling because the opportunity to teach students to deal with the dilemmas of the medical profession adequately is also lost. Thus, emotionally unprepared graduate professionals who are more prone to psychic disorders such as the Burnout Syndrome, characterized by professional exhaustion due to the difficulty in dealing with several stressful factors of the work environment, among which the terminality of life and all the suffering and anguish that arise from it ${ }^{21,22}$. 
Therefore, the existence of spaces to speak with qualified listeners during the undergraduate course is important since it helps students in the healthy processing of the experiences and attributes meaning to them in the context of medical training. For Wear ${ }^{19}$, students need examples that inspire them to deal with terminally ill patients, and it is up to the professors and preceptors to act as such by detecting the feelings and difficulties that the students face with such patients and sharing their own experiences as a guidance strategy.

On the other hand, if well used, the academic end-of-life experiences may be valuable teaching and learning opportunities. Lessons such as good principles in the doctor-patient relationship, discussions on bioethical issues, strategies to cope with death, notions of self-care and professionalism, teamwork, and self-criticism could be passed on to future physicians by using these experiences ${ }^{18,23}$.

Regarding the theoretical approach to death and dying, the Family and Community Medicine, Bioethics, and Medical Psychology courses stood out for centering most of the approach to the subject. The humanistic nature of such courses may explain the fact that they concentrated the approaches to end-of-life issues, which in themselves are fraught with human, ethical, and moral conflicts.

However, the ideal scenario would be to have the discussions about death and dying occur longitudinally throughout the Medicine course instead of being concentrated exclusively on a few moments and courses. Discussing palliative care, communication of bad news, and spirituality in traditionally "technical" courses such as Internal Medicine and Surgery, for example, in which the practical experiences with terminal patients may be more frequent, would contribute to the understanding of the importance of humanization and of the holistic view of the human being whatever the medical specialty, demystifying the idea of the physician who only treats and cures in favor of the physician who cares independently of his/her specialty and of the patient's prognosis.

Nevertheless, it is challenging to integrate humanistic content into the curricula of medical schools, which, according to the literature, is due to several reasons: inadequate methodologies, lack of preparation of professors, little interest of students and professors in the subject. Rios et al. ${ }^{24}$ warned that there is a tendency to regard the subjects of humanistic fields as something "that does not interest physicians". The following comment of a participant in this study seems to corroborate this fact:

The proposal to debate the themes by the respective courses and their people in charge was enough to promote the emer- gence of several questions. However, the routine of the course makes us believe that, at that moment, there are more important subjects to be addressed such as clinical, for example.

From this comment, one may notice an alignment with the biomedical view characterized by overvaluing disease and technique - "clinical is more important" - to the detriment of the sick patient and of the human aspects of the profession which, due to the complexity that characterizes them, gives rise to "several questions".

Hence, better transdisciplinary teaching training of professors is necessary to reinforce the view of the human being in its various dimensions and demonstrate that the undergraduate course is the right time to work on these other "questions" - social, psychic, spiritual... - which will inevitably be present when dealing with patients. A beneficial resource would be to promote interdisciplinary and multi-professional discussions contemplating the various aspects of care and based on cases experienced by the students themselves.

In a study with several health courses that did not include the medical course, it was found that $75.4 \%$ of the students had not had any discussion about death and dying and $87.1 \%$ had not experienced a patient death during the undergraduate course. On the other hand, most participants of our study declared to have discussed the theme at some point in the medical course and had a patient death experience during medical training. Thus, we verify that contact with death is more frequent in medical school than in other health courses although the quality and effectiveness of this contact are questioned by students ${ }^{14}$.

For most participants in this study, the theoretical approach to death and dying was superficial and insufficient, which means they contributed little to generate reflection and develop skills on the subject. In justifying their answers, the students emphasized the little time devoted to addressing the subject, the concentration of the theme in few courses, and the lack of coherence between what was addressed in theory and the reality observed in practice. Some participants even criticized the Medicine course, which they called "uncritical", "thoughtless", and "content-driven", in line with other studies that also criticized the excessively theoretical approach to death in Medicine courses, while there is little encouragement to develop practical skills to deal with such issues ${ }^{25,26}$.

In this sense, it is emphasized that teaching about death and dying requires more than transferring ethical and moral concepts, legal norms, and protocol conduct. After all, regarding learning about end-of-life care, the specialists have stressed that nothing replaces the experience with patients. 
The main thing is to give priority to the contact with terminally ill patients in the practical internships, allowing the development of the critical-reflexive capacity of the students over themselves and others from such experiences ${ }^{19}$.

Through their comments, some students expressed ideas in this regard:

The best way to develop skills to deal with situations of death and terminality of life is through self-reflection.

In my opinion, the best place to learn to deal with these issues is in medical practice, in hospitals and preferably with good preceptors willing to interact with the student.

Ellman et al. ${ }^{27}$ showed that it is possible to organize this type of internship without it being an extra activity in the students' curriculum or an additional burden on the professors since these experiences occurred during regular internship activities. Macleod et al. ${ }^{28}$ reported, in what they called a "transforming learning experience", that living and learning about death and dying are possible in a variety of settings and at any time in the undergraduate course.

Elisabeth Kübler-Ross (p. 36) ${ }^{29}$ reiterates that:

The most important thing is our attitude and ability to face fatal diseases and death. If this is a major problem in our private lives, if death is seen as a horrendous, ghastly taboo, we will never face it calmly when helping a patient. [...] If we are unable to face death with serenity, how can we help our patients?

Although studies, books, and theories present paths and possibilities, the security and wisdom when facing the end of life will be natural consequences of the clinical and human experience arising from the direct relationship with patients, their families, dramas, and conflicts. Therefore, providing students with experiences with dying patients and valuing them to the fullest in the training process through reflection is the best education that can be given regarding death and dying.

\section{CONCLUSIONS}

As a conclusion, it was possible to observe that, in the participants' imagination, there is a strong association between negative feelings and the idea of death. At the same time, one observes a predominance of a profile of attitude towards death neutral acceptance - that views it as a natural phenomenon of life. To understand this apparent paradox, we admit that the neutral attitude could simply represent an effective defense mechanism to reduce the fear raised by death instead of being authentic tranquility towards it, and is likely a posture assimilated by the students when observing the conduct of more experienced professionals.

We also postulate that the behavior towards death is influenced both by sociocultural elements derived from social life and by academic experiences resulting from the undergraduate course, so it is important to think and rethink such influences constantly throughout medical training.

Besides, in the medical school, an attitude of detachment from death still prevails which is little discussed despite being much experienced. As a result, the approach of death and dying remains concentrated in few predominantly humanistic courses. In the participants' perception, this promotes little reflection and has limited contribution to developing skills to manage end-of-life situations, with a predominance of the biomedical model of teaching to the detriment of a holistic view of the patient and the ethical-moral and humanistic issues of the medical profession. Hence, it is necessary to prepare professors better to teach end-of-life issues in order to promote broad and transdisciplinary approaches on the subject at different times and opportunities of the medical training.

Finally, we emphasize that learning about death and dying requires direct experience with the patients. It is essential that moments of contact with dying patients are made possible during medical training and properly accompanied by experienced professionals who can awaken in students not only the human aspect of Medicine but also the capacity of self-reflection, a crucial element for end-of-life care.

\section{REFERENCES}

1. Rodrigues JC. Tabu da morte. $2^{\underline{a}}$ ed. Rio de Janeiro: FIOCRUZ; 2006.

2. Ariès P. História da Morte no Ocidente: da Idade Média aos nossos dias. $2^{\underline{a}}$ ed. Rio de Janeiro: Nova Fronteira, 2012.

3. Elias N. A solidão dos moribundos [livro digital]. $1^{\underline{a}}$ ed. Rio de Janeiro: Zahar; 2001.

4. Barros JAC. Pensando o processo saúde doença: a que responde o modelo biomédico? Saúde e Soc. 2002;11(1):67-84.

5. Pessini L. Dignidade e Solidariedade no adeus à vida. In: Problemas atuais de bioética. São Paulo: Loyola; 2012. p. 437-58.

6. Starzewski Júnior A, Rolim LC, Marrone LC. O preparo do médico e a comunicação com familiares sobre a morte. Rev Assoc Med Bras. 2005;51(1):11-6.

7. Siqueira JE. Definindo e aceitando a terminalidade da vida. In: Moritz RD, organizador. Conflitos bioéticos do viver e do morrer [livro digital]. Brasília: Conselho Federal de Medicina; 2011. 
8. Wong PTP, Reker GT, Gesser G. The Death Attitude Profile-Revised (DAP-R): a multidimensional measure of attitudes towards death. Ontario: Trent University; 1991. Disponível em: http://www.drpaulwong.com/wp-content/uploads/2013/09/DEATH-attitude-Profile-Revised-Chapter.pdf

9. Loureiro LMJ. Tradução e adaptação da versão revista da Escala de Avaliação do Perfil de Atitudes acerca da Morte (EAPAM). RevEnferm Ref. 2010;3(1):101-8.

10. Minayo MC. O desafio do conhecimento: pesquisa qualitativa em saúde. 1ª̣ed. São Paulo: HUCITEC; 1992.

11. Alves ZMMB, Silva MHGFD. Análise qualitativa de dados de entrevista: uma proposta. Paid. (Riberão Preto) [Internet]. 1992;2 (Fev/Jul):61-69.

12. Duarte AC, Almeida DV, Popim RC. A morte no cotidiano da graduação: um olhar do aluno de medicina. Interface Commun Heal Educ. 2015;19(55):1207-19.

13. Ribeiro HJ. Atitude e ansiedade face a morte: perfil dos graduandos da área da saúde. Brasília; 2014. Graduação [Trabalho de Conclusão de Curso] - Universidade de Brasília (UnB): Faculdade de Ceilândia.

14. Souza MCS, Sousa JM, Lago DMSK, Borges MS, Ribeiro LM, Guilhem DB. Avaliação do perfil de atitudes acerca da morte: estudo com graduandos da área da saúde. Texto e Context. Enferm. [Internet]. 2017;26(4):1-8.

15. Eizirik CL, Polanczyk GV, Eizirik M. O médico, o estudante de Medicina e a morte. Rev AMRIGS. 2000;44(1,2):50-5.

16. Azeredo NSG. O acadêmico de medicina frente à morte: questões para se (re)pensar a formação. Porto Alegre; 2007. Mestrado [Dissertação]. Universidade Federal do Rio Grande do Sul: Faculdade de Medicina. Programa de Pós-Graduação em Ciências Médicas: Pediatria.

17. Mascia AR, Silva FB, Lucchese AC, Marco MA, Martins MCFN, Martins LAN. Atitudes frente a aspectos relevantes da prática médica: estudo transversal randomizado com alunos de segundo e sexto anos. RevBrasEduc Med. 2009;33(1):40-8.

18. Rhodes-kropf J, Carmody SS, Seltzer D, Redinbaugh E, Gadmer N, Block SD, et al. " This is just too awful ; I just can't believe I experienced that . . .": Medical Students ' Reactions to Their "Most Memorable" Patient Death. Acad Med. 2005;80(7):634-40.

19. Wear D. "Face-to-face with it": Medical Students' Narratives about Their End-of-life Education. Acad Med. 2002;77(4/ April):271-7.

20. Carpena LAB. Morte versus sentimentos: uma realidade no mundo dos acadêmicos de medicina. Rev Gaúcha Enferm. 2000;21(1):100-22.
21. Carreiro BO, Dantas TRS, Pascoal FFS, Moraes MN, Cordeiro RC, Ferreira Filha MO. Prevalência da síndrome de burnout em médicos de uma instituição hospitalar federal de ensino. J Res Fundam Care. 2015;7:39-48.

22. Sobrinho CLN, Barros DS, Tironi MOS, Marques Filho ES. Médicos de UTI: prevalência da Síndrome de Burnout, características sociodemográficas e condições de trabalho. Rev Bras Educ Med. 2010;34(1):106-15.

23. Obando FS, Amado ED. La Formación Ética de los Estudiantes de Medicina: la Brecha entre el Currículo Formal y el Currículo Oculto. Acta Bioeth [Internet]. 2007;13(1):10713.

24. Rios IC, Lopes Junior A, Kaufman A, Vieira JE, Scanavino MDT, Oliveira RA. A integração das disciplinas de humanidades médicas na Faculdade de Medicina da USP: um caminho para o ensino. Rev Bras Educ Med. 2008;32(1):112-21.

25. Azeredo NSG, Rocha CF, Carvalho PRA. O enfrentamento da morte e do morrer na formação de acadêmicos de Medicina. Rev Bras Educ Med. 2011;35(1):37-43.

26. Camargo AP, Nunes LMF, Reis VKR, Breschiliare MFP, Morimoto RJ, Moraes WAS. O ensino da morte e do morrer na graduação médica brasileira: artigo de revisão. Rev UNINGÁ. 2015;45(jul-set):44-51.

27. Ellman MS, Rosenbaum JR, Bia M. Development and Implementation of an Innovative Ward-Based Program to Help Care Experience. Acad Med. 2007; 82(7):723-7.

28. Macleod RD, Parkin C, Pullon S, Robertson G. Early clinical exposure to people who are dying: learning to care at the end of life. Med Educ. 2003; 37:51-8.

29. Kübler-Ross E. Sobre a morte e o morrer: o que os doentes terminais têm para ensinar a médicos, enfermeiras, religiosos e a seus próprios parentes. $9^{\underline{a}}$ ed. São Paulo: WMF Martins Fontes; 2012.

\section{CONTRIBUTIONS}

Daniel Teixeira Marques participated in all stages of the project. Maria Liliane Gomes Santos and Romeu Paulo Martins Silva participated in the design, analysis, result interpretation, and final review of the project. Marcelo Xavier de Oliveira participated in the analysis, result interpretation, and final review of the project. Rodrigo Pinheiro Silva participated in the final review of the project.

\section{CONFLICT OF INTERESTS}

We declare no conflicts of interest. 


\section{RESEARCH PROMOTION INSTITUTION}

There was no subsidy to this project with financial resources. However, the Universidade Federal do Acre acted as a partner in its execution.

\section{HUMAN RESEARCH ETHICS COMMITTEE}

Project approved by the REC of the Hospital das Clínicas of the state of Acre, Brazil.

\section{POSTAL ADDRESS}

Daniel Teixeira Marques

Rua Adib Faiad, nº 20, Setor dos Bancários

CEP: 75200-000 - Pires do Rio, Goiás, Brasil

E-mail: daniel_dtm_6@yahoo.com.br 